\title{
Pharmacognosy
}

\section{Chemical composition and antinociceptive activity of volatile fractions of the aerial parts of Solidago chilensis (Compositae)}

\author{
Simone Sacramento Valverde ${ }^{1,2,4,5}$, Stefânia Priscilla de Souza ${ }^{1}$, Temistocles Barroso de Oliveira ${ }^{2}$, \\ Andressa Maia Kelly ${ }^{2}$, Nathalia Ferreira Costa ${ }^{3}$, Andrea Surrage Calheiros ${ }^{3}$, Keila dos Santos Cople Lima ${ }^{1}$, \\ Valber da Silva Frutuoso ${ }^{3} \&$ Antônio Luís dos Santos Lima ${ }^{1}$
}

\begin{abstract}
Thirty-six compounds were identified from aerial parts of Solidago chilensis cultivated at PAF/FIOCRUZ campus in Rio de Janeiro city (RJ) using solid-phase microextraction (HS-SPME) and gas chromatography-mass spectrometry (GC-MS) analysis. These compounds are mainly non-oxygenated mono and sesquiterpenes. Germacrene D is the major compound of two the essential oil analyzed samples (12 to 23\%) and of two of the volatiles samples analyzed by SPME (central stems and dry inflorescences samples). Limonene is the major compound in the fresh inflorescences sample (about 21\%). The bornil acetate is present in both volatile fractions $(16 \%)$ and essential oils (7-8\%). All the essential oils samples evaluated shown a great antinociceptive activity, considering the used dose of the samples $(1 \mathrm{mg} / \mathrm{kg})$ and the standard substance $(50 \mathrm{mg} / \mathrm{kg})$. Solidago chilensis is one of Brazil arnicas and it is a medicinal plant widely used by the brazilian population. Other plants of the genus Solidago are also used in traditional medicine in North America and Europe. This is the first report of SPME analysis from Solidago genus and of the antinociceptive effect from Solidago chilensis essential oil.
\end{abstract}

Key words: antinociceptive activity, essential oil, Germacrene D, Solidago chilensis, SPME.

\section{Resumo}

Trinta e seis compostos foram identificados à partir de partes aéreas de Solidago chilensis cultivadas na PAF/ FIOCRUZ, na cidade do Rio de Janeiro, usando microextração em fase sólida (MEFS) e analisados por cromatografia gasosa-espectrometria de massa (CG-EM). Estes compostos são principalmente mono terpenos não oxigenados e sesquiterpenos. O Germacreno D é o composto majoritário de duas amostras de óleo essencial analisadas (12 a 23\%) e de duas amostras voláteis analisadas por MEFS. Limoneno é o composto majoritário da amostra de inflorescências frescas (cerca de $21 \%$ ). $\mathrm{O}$ acetato de bornila está presente em ambas as frações, voláteis (16\%) e óleos essenciais (7-8\%). Todas as amostras de óleos essenciais avaliadas apresentaram boa atividade antinociceptiva, considerando a dose utilizada das amostras $(1 \mathrm{mg} / \mathrm{kg})$ e a substância padrão $(50 \mathrm{mg} / \mathrm{kg})$. Solidago chilensis é uma das arnicas brasileiras e é uma planta medicinal amplamente utilizada pela população brasileira. Outras plantas do gênero Solidago também são utilizadas na medicina tradicional na América do Norte ena Europa. Este éo primeiro relato da análise de MEFS do gênero Soligado e do efeito antinociceptivo do óleo essencial de Solidago chilensis. Palavras-chave: atividade antinociceptiva, óleo essencial, Germacreno D, Solidago chilensis, MEFS.

\section{Introduction}

The Solidago genus is the biggest of the Compositae family, and includes about 120 species, most of them occurring in North America. Many members of the Solidago genus and of all Compositae family are important as cut flowers and ornamental crops, as well as being medicinal and aromatic plants, many of which produce essential oils used in folk and modern medicine and in the cosmetics, pharmaceutical industries and as beverages (Abad et al. 2013). Species of Solidago genus have been reported to possess antibacterial, anti-inflammatory,

\footnotetext{
${ }^{1}$ Military Institute of Engineering, Chemical Engineering Department, General Tibúrcio Square 80, Urca, 22290-270, Rio de Janeiro, RJ, Brazil.

${ }^{2}$ FIOCRUZ - Farmanguinhos, Pharmaceutical Technology Institute, Sizenando Nabuco Street 100, Manguinhos, 21041-250, Rio de Janeiro, RJ, Brazil.

${ }^{3}$ FIOCRUZ - Oswaldo Cruz Institute, Sizenando Nabuco Street 100, Manguinhos, 21041-250, Rio de Janeiro, RJ, Brazil.

${ }^{4}$ ORCID: <https://orcid.org/0000-0001-9043-3739>

${ }^{5}$ Author for correspondence: simonevalverde@far.fiocruz.br
} 
spasmolytic, and carminative properties (Sung et al. 1999). Solidago chilensis Meyen (also called as S. microglossa, S. odora (Oliveira et al. 1998) is a natural species in Chile, with distribution in South America, including the Northeast, Midwest, Southeast and Southern Brazil. Its use increases based on folk tradition in which its inflorescences and roots are used as anticephalgic in the treatment of injuries, such as anti-inflammatory since the the end of the $19^{\text {th }}$ century, after the arrival of the European immigrants, principally the Italians, although its medicinal properties were known since the $13^{\text {th }}$ century. These new settlers called the Solidago plants they encountered in Brazil "arnica" due to the similar aromas and medicinal properties to that of A. montana L. from Europe (Vieira 1999; Miguel 2007). So, this species has been used by population in place to the hepatotoxic exogenous species Arnica montana L. (Digest 2001; Mercandeli et al. 2012). Despite of the great use by population, mainly in South America, little is known about the species called "Brazilian arnicas" because very few studies have examined their effectiveness in human health (Silva et al. 2010).

The hydroalcoholic extract of Solidago chilensis Meyen has been evaluated and suggested that in oral therapeutic doses (till $100 \mathrm{mg} / \mathrm{kg}$ ) there is no health risk in the acute toxicity test (Paula-Freire et al. 2006). Flavonoids, labdane and clerodane diterpenes, saponins, carotenoids, tannins, essential oil and other substances are chemically and biologically described for the Solidago species (Torres 1985; Valverde et al. 2013).

Volatile oils typically contain a complex mixture of low boiling components which are composed predominantly of terpenoid compounds derived by the mevalonate pathway or composed predominantly of aromatic substances derived by the shikimate pathway. These oils are widely used in the whole world in aromatherapy, in perfumery, to produce cosmetic (hygiene and health care formulations as toothpastes, mouthwashes) as natural flavouring, as spice blends and as medicines due to their therapeutic properties (generally they have a broad spectrum of bioactivity) due to the presence of several active compounds or they are added on it for its flavouring purposes. Those oils are still used in various human activities including religious ceremonies, adornments, sensory perception and others personal uses (Sangwan et al. 2001; Schnaubelt 2005).

The essential oil of the Solidago genus have been chemically and biologically previously reported to many species as S. altissima, S. gigantea (Fujita et al. 1979), S. virgaurea (Fujita 1991), S. canadensis
(Weyerstahl et al. 1993; Kasali et al. 2002), S. graminifolia (Kalemba 1992), S. virgaurea (Kalemba 1998), S. chilensis (Gressler et al. 2003; Duarte et al. 2005) and these biological activities described were antifungal and (Gressler et al. 2003; Li et al. 2011), antimicrobial (Duarte et al. 2005). The essential oil from Solidago canadensis leaf was tested for cytotoxic activities against three tumor cell lines (Yoshihara et al. 1969; Steliopoulos et al. 2002). There are no previous reports about the antinociceptive activity neither the SPME analysis of the Solidago chilensis Meyen essential oil.

\section{Material and Methods}

This is a no human subject research, all experimental protocols used in this work were approved and performed in accordance with the recommendations of Commission of Ethics for Use of Animals (CEUA/FIOCRUZ) under numbers 002/08 and 033/09.

\section{Plant material}

Solidago chilensis Meyen was cultivated at Phytomedicine Agroecological Platform (PAF), FIOCRUZ, Rio de Janeiro city, RJ, Brazil (22'93'52.74'"S; 43³9'89.16”'W). Their inflorescences are collected in the summer, between December and March, when they are produced due to increased sunlight. The central stems were collected from the same producers of inflorescences plants. The species identification was performed by Mariana Reis de Brito, Botany Herbarium of the Department of the Institute of Biology/UFRJ and a voucher specimen was deposited under the code 32689/RFA.

\section{Post-harvest processing}

Medicinal plants in post-harvest processing should be dried between 30 and $60{ }^{\circ} \mathrm{C}$, and medicinal plants containing essential oils should be dried at temperatures below $40{ }^{\circ} \mathrm{C}$ (Azar et al. 2012). Aerial parts of $S$. chilensis were dried in electric oven inflated at $37{ }^{\circ} \mathrm{C}$ with air velocity of $0.45 \mathrm{~m} / \mathrm{s}$ and relative humidity not exceeding $30 \%$, for 48 hours. The mass of $S$. chilensis for essential oil extraction was approximately $310 \mathrm{~g}$ of fresh plant or the equivalent when dry. The moisture content in flowers usually varies between 15 and $80 \%$. Were found $40 \%$ of moisture content in inflorescences from $S$. chilensis.

Headspace solid phase micro-extraction An SPME (Solid Phase Micro-Extration) holder (Supelco, Bellefonte, PA) was used in performing 
the experiments. A fused silica fiber coated with a $50 / 30 \mu \mathrm{m}$ layer of polydimethylsiloxane (PDMS) was chosen to extract the volatile components from the $S$. chilensis. The fiber was conditioned following the manufacturer's instructions previous to its use. Approximately $1 \mathrm{~g}$ of sample was placed in a $4 \mathrm{~mL}$ vial closed with a plastic film. Once the desired temperature had been reached in a water bath $(60$ ${ }^{\circ} \mathrm{C}$ ), the vial was placed inside the bath and was allowed to condition for the equilibrium time (no fiber exposition). After the equilibrium time, the fiber was introduced into the vial and exposed to the headspace of the sample during 20 minutes.

\section{Extraction of essential oil}

The aerial parts from Solidago chilensis Meyen were separated to steam distillation of the essential oil and they are cut into small pieces. The essential oil extraction was carried out by steam distillation, using the modified apparatus Clevenger adapted to a round bottom flask with 2 liters of capacity. Triplicate samples of portions of $130 \mathrm{~g}$ of plant material, were extracted separately by the same technique. The extraction process was performed during 3 hours, maintaining the boiling water. After that, the essential oil has been separated from hydrolate obtained following centrifugation for $10 \mathrm{~min}, 4,000 \mathrm{rpm}$, with the aid of Pasteur pipette. The organic phase was filtered through anhydrous sodium sulfate. The samples were stored at $-20^{\circ} \mathrm{C}$ until analysis.

\section{GC-MS}

The chromatographic separation was performed on a column of $30 \mathrm{~m} \times 0.32 \mathrm{~mm}$ and $0.2 \mathrm{~mm}$ thick, with $5 \%$ diphenyl $95 \%$ dimethylpolysiloxane as stationary phase. The chromatographic conditions were: linear heating from 30 to $240^{\circ} \mathrm{C}$ with a rate of 10 ${ }^{\circ} \mathrm{C} / \mathrm{min}$; gun "split-splitless" rate "split" of $1 / 100$, and flow rate of $1 \mathrm{~mL} / \mathrm{min}$. SCAN mode was used for $\mathrm{m} / \mathrm{z}$ 15 to 300 , helium as mobile phase, manual injection and flow rate of $1.00 \mathrm{~mL} / \mathrm{min}$. The heating was linear from $40{ }^{\circ} \mathrm{C}$ to $300{ }^{\circ} \mathrm{C}$ with a rate of $10^{\circ} \mathrm{C} / \mathrm{min}$.

\section{Analysis and identification of essential oil by GC/MS}

Shimadzu GC/MS QP-2010 (Kyoto, Japan) spectrometer was used in the electron impact (EI) mode for the quantitative analysis. The ionization voltage and temperature of injector and ion source were $70 \mathrm{eV}, 250$ and $280^{\circ} \mathrm{C}$, respectively. The mass spectrometer scanned from 30 to $400 \mathrm{~m} / \mathrm{z}$. A DB5 capillary column $(30 \mathrm{~m} \times 0.25 \mathrm{~mm} ; 0.25 \mu \mathrm{m}$ film thickness) was used for the separation. The oven temperature was programmed at $60{ }^{\circ} \mathrm{C}$ (isothermal for $2 \mathrm{~min}$ ) which was ramped to $250^{\circ} \mathrm{C}$ at $4{ }^{\circ} \mathrm{C} / \mathrm{min}$. Helium was used as the carrier gas with a flow rate of $1.0 \mathrm{~mL} / \mathrm{min}$ with an injector volume of $1 \mu \mathrm{L}$ using a 1:20 split ratio.

Compounds of interest were identified by comparing their retention times with that of authentic standards injected separately under the same GC-MS conditions and according with literature values (Fig. 1). Peaks compounds were identified by comparing its mass fragmentation pattern with that of standard compounds as well with data available spectral library (Wiley NIST Libraries) of the instrument. All analysis were performed in triplicate and quantification of each constituent obtained by standardization of the areas $(\%)$.

\section{Pharmacological assays}

Animals

Male Swiss mice and Wistar rats weighing 2330 and $130-200 \mathrm{~g}$ respectively were used. The animals were obtained from the animal-breeding colony at the Oswaldo Cruz Institut Foundation (FIOCRUZ) and maintained in the animal room of the Department of Physiology and Pharmacodynamics, in Oswaldo Cruz Institut (IOC/FIOCRUZ), with free access to pelleted diet and water and a controlled period of light/darkness of $12 / 12 \mathrm{~h}$. The animals were allowed to adapt to the laboratory for at least 2 hours before testing and were used only once. The experiments in this study received prior approval from the Oswaldo Cruz Institut Foundation's Animal Welfare Committee. The license for use of the animals was granted by Center for the Study of Animal Use (CEUA/FIOCRUZ) under numbers 002/08 and 033/09. After the experimental procedures animals were euthanized in $\mathrm{CO}_{2}$ chamber.

\section{Antinociceptive effect}

The EOCS, EODI and EOFI samples were evaluated for their analgesic activity through Collier's test acetic acid induced writhes in mice to evaluate their antinociceptive effect (Sousa 2011). The amount of contortions was evaluated for 10 minutes, beginning the registers after 5 minutes of the injection of the stimulus. The doses of EOCS, EODI and EOFI $(1 \mathrm{mg} / \mathrm{Kg})$, and the control analgesic, diclofenac (50 $\mathrm{mg} / \mathrm{Kg}$ ), were administrated orally (p.o.), always an hour after the induction of pain. The control group was treated with saline solution + DMSO (diluent).

\section{Statistical analysis}

Statistical significance was determined by a one-way analysis of variance, followed by Student's- 

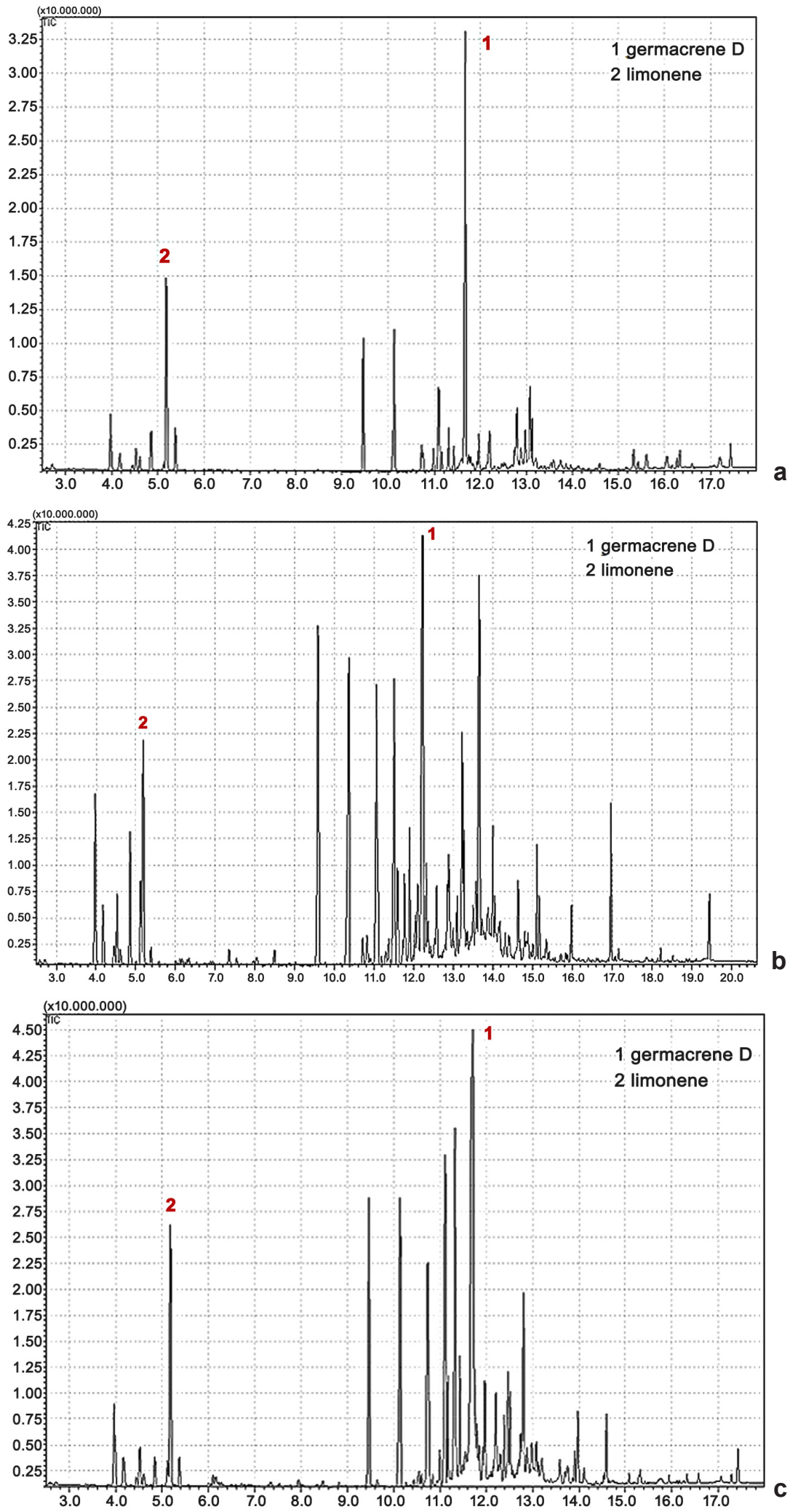

Figure 1 - a-c. Chromatograms of GC analysis of the essential oils from the fresh inflorescences - a. EOFI; b. dry inflorescences, EODI; c. central stem EOCS. 
Neuman-Keuls test (Prism 4, GraphPad, La Jolla, CA, USA). The results were considered significant for values of $P \leq .05$.

\section{Results and Discussion}

In order to identify the largest possible number of volatile compounds of the $S$. chilensis by HSSPME (Headspace Solid Phase Microextraction) the PDMS (Polydimethylsiloxane) fiber was chosen. The PDMS fiber is more suitable for the analysis of low molecular weight polar and non polar compounds. Table 1 lists the volatiles, obtained by SPME, of the analyzed samples CSV (Central Stem Volatiles), DIV (Dry Inflorescences Volatiles) and FIV (Fresh Inflorescences Volatiles) of S. chilensis.

Germacrene D is the major constituent of the CSV and DIV volatiles samples, and it represents $12 \%$ of the CSV and $23 \%$, of the DIV. In spite of FIV sample Germacrene D has been found in large amounts $(20.8 \%)$, limonene is the compound with the highest concentration of $20.95 \%$. This hydrocarbon is a widely distributed metabolic compound in S. chilensis plant species and it is considered to be a key intermediate in the biosynthesis of many sesquiterpenes from farnesyl diphosphate (Bülow et al. 2000; Steliopoulos et al. 2002; Shah et al. 2012). According to Vila and Gressler (Vila et al. 2002; Gressler et al. 2003), the pumiloxide, a labdane diterpene, was found as the major compound in the essential oil from leaves and inflorescences of Solidago chilensis Meyen collected in Pérez (Rosario, Argentina). In the $S$. chilensis cultivated at Phytomedicine Agroecological Platform (PAF), FIOCRUZ/RJ, there was no pumiloxide found. The diterpene compounds found were phytol and solidagenone (also a labdane diterpene) (Tab. 2) The difference in concentration of germacrene D can be explained

Table 1 - Identified compounds by GC-MS in volatiles from different plant material ${ }^{1}$ by HS-SPME (PDMS) of Solidago chilensis Meyen.

\begin{tabular}{lccccc}
\hline \multirow{2}{*}{ Compound $^{2}$} & ${\text { Linear retention } \text { index }^{3}}$ & & \multicolumn{4}{c}{ Relative content (\%) } \\
\cline { 2 - 6 } & sample & Electron impact mass spectrometric data & CSV & DIV & FIV \\
\hline$\alpha$-pinene & 942 & $93 ; 91 ; 92 ; 77 ; 121 ; 136$ & 4.62 & 3.23 & 5.59 \\
camphene & 953 & $93 ; 121 ; 79 ; 107 ; 136$ & - & 1.28 & 2.36 \\
$\beta$-pinene & 983 & $93 ; 41 ; 69 ; 91,136$ & 1.78 & 1.79 & 3.41 \\
$\beta$-myrcene & 992 & $93 ; 41 ; 69 ; 91 ; 136$ & - & - & 2.29 \\
$\alpha$-phellandrene & 1007 & $93 ; 91 ; 77 ; 92 ; 136$ & 2.6 & 1.5 & 4.42 \\
o-cymene & 1025 & $119 ; 134 ; 91 ; 117$ & 1.38 & 1.27 & - \\
$\beta$-phellandrene & 1033 & $93 ; 77 ; 91 ; 136$ & - & - & 1.26 \\
limonene & 1034 & $68 ; 67 ; 93 ; 79 ; 121 ; 136$ & 6.77 & 7.54 & 20.95 \\
$(Z)-\beta$-ocimene & 1040 & $93 ; 91 ; 79 ; 77 ; 41 ; 136$ & - & 1.3 & 6.08 \\
bornyl acetate & 1284 & $95 ; 43 ; 93 ; 136 ; 121 ; 196$ & 12.95 & 9.03 & 16.72 \\
$\alpha$-cubebene & 1353 & $1119 ; 105 ; 161$ & 1.85 & - & - \\
copaene & 1378 & $161 ; 91 ; 105 ; 119 ; 133$ & 3.84 & 3.21 & 1.92 \\
$\beta$-bourbonene & 1385 & $81 ; 29 ; 80 ; 123 ; 161 ; 204$ & 11.87 & 7.58 & 2.1 \\
isocaryophyllene & 1411 & $69 ; 161 ; 93 ; 41 ; 93 ; 105 ; 204$ & 4.18 & - & - \\
$\beta$-caryophyllene & 1420 & $93 ; 133 ; 91 ; 41 ; 79 ; 69 ; 204$ & 10.91 & 10.72 & 4.94 \\
$\gamma$-elemene & 1434 & $93 ; 81 ; 67 ; 41 ; 107 ; 147 ; 161$ & 11.68 & 8.14 & 5.97 \\
$\alpha$-humulene & 1443 & $93 ; 80 ; 121 ; 41 ; 204$ & 3.58 & 3.68 & 1.32 \\
$(Z)-\beta$-farnesene & 1445 & $119 ; 93 ; 41 ; 91 ; 204$ & - & 11.82 & 1.42 \\
$\gamma$-muurolene & 1479 & $161 ; 93 ; 105 ; 119 ; 204$ & 1.31 & - & - \\
germacrene D & 1482 & $161 ; 105 ; 91 ; 119 ; 79 ; 204$ & 19.35 & 22.43 & 20.8 \\
\hline
\end{tabular}

${ }^{1} \mathrm{CSV}=$ central stem volatiles; DIV $=$ inflorescences volatiles; FIV $=$ fresh inflorescences.

${ }^{2}$ Compounds are listed in order of their elution from a DB- 5 column.

${ }^{3} \mathrm{RI}=$ retention indices relative to $\mathrm{C} 8-\mathrm{C} 28 n$-alkanes. 
Table 2 - Chemical composition of the volatile compounds detected from the essential oil from Solidago chilensis Meyen ${ }^{1}$.

\begin{tabular}{|c|c|c|c|c|c|}
\hline \multirow{2}{*}{ Compound $^{2}$} & \multirow{2}{*}{$\frac{\text { Linear retention index }}{3}$} & \multirow{2}{*}{$\begin{array}{l}\text { Electron impact mass } \\
\text { spectrometric data }\end{array}$} & \multicolumn{3}{|c|}{ Relative content ${ }^{\mathrm{a}}(\%)$} \\
\hline & & & EOCS & EODI & EOFI \\
\hline$\alpha$-pinene & 940 & $93 ; 91 ; 92 ; 77 ; 121 ; 136$ & 3.89 & 2.24 & 3.1 \\
\hline camphene & 951 & $93 ; 121 ; 79 ; 107 ; 136$ & - & - & 0.98 \\
\hline$\beta$-pinene & 982 & $93 ; 41 ; 69 ; 91,136$ & 1.39 & 0.9 & 1.2 \\
\hline$\beta$-myrcene & 994 & $93 ; 41 ; 69 ; 91 ; 136$ & - & - & 0.76 \\
\hline$\alpha$-phellandrene & 1005 & $93 ; 91 ; 77 ; 92 ; 136$ & 2.67 & - & 2.07 \\
\hline o-cymene & 1023 & $119 ; 134 ; 91 ; 117$ & 1.69 & - & - \\
\hline limonene & 1032 & $68 ; 67 ; 93 ; 79 ; 121 ; 136$ & 4.41 & 5.745 & 10.07 \\
\hline$(Z)-\beta$-ocimene & 1043 & $93 ; 91 ; 79 ; 77 ; 41 ; 136$ & - & 0.6 & 2.13 \\
\hline bornyl acetate & 1284 & $95 ; 43 ; 93 ; 136 ; 121 ; 196$ & 8.19 & 6.9 & 7.06 \\
\hline$\alpha$-cubebene & 1352 & $119 ; 105 ; 161$ & 1.2 & 2.18 & - \\
\hline copaene & 1379 & $161 ; 91 ; 105 ; 119 ; 133$ & 1.85 & 2.23 & 1.27 \\
\hline$\beta$-bourbonene & 1383 & $81 ; 29 ; 80 ; 123 ; 161 ; 204$ & 7.32 & 6.39 & 2.03 \\
\hline Isolongifolene & 1388 & $131 ; 187 ; 91 ; 146 ; 202$ & 2.24 & 1.84 & 1.62 \\
\hline$\beta$-cubebene & 1389 & $161 ; 105 ; 119 ; 91 ; 204$ & - & 0.69 & 2.69 \\
\hline$\alpha$-gurjunene & 1412 & $105 ; 161 ; 204 ; 119 ; 91$ & 1.19 & 1.16 & - \\
\hline$\beta$-caryophyllene & 1419 & $93 ; 133 ; 91 ; 41 ; 79 ; 69 ; 204$ & 6.87 & 9.03 & 5.51 \\
\hline$\gamma$-elemene & 1428 & $93 ; 81 ; 67 ; 41 ; 107 ; 161$ & 8.40 & 7.54 & 7.78 \\
\hline aromadendrene & 1439 & $145 ; 159 ; 202 ; 131 ; 105 ; 204$ & 2.93 & 1.86 & 2.34 \\
\hline$\alpha$-guaiene & 1440 & $105 ; 107 ; 93 ; 147 ; 204$ & 3.81 & 2.3 & - \\
\hline$\alpha$-humulene & 1441 & $93 ; 80 ; 121 ; 41 ; 204$ & 2.52 & 2.69 & 1.28 \\
\hline$(Z)$ - $\beta$-farnesene & 1443 & $119 ; 93 ; 41 ; 91 ; 204$ & 2.17 & 9.69 & 2.64 \\
\hline$\gamma$-muurolene & 1480 & $161 ; 93 ; 105 ; 119 ; 204$ & - & 0.74 & - \\
\hline germacrene D & 1483 & $161 ; 105 ; 91 ; 119 ; 79 ; 204$ & 12.11 & 22.01 & 23.3 \\
\hline$\alpha$-bisabolene & 1507 & $93 ; 119 ; 41 ; 105 ; 204$ & - & 0.83 & - \\
\hline$\delta$-cadinene & 1526 & $161 ; 134 ; 105 ; 119 ; 204$ & - & 0.91 & - \\
\hline$\delta$-calacorene & 1540 & $157 ; 142 ; 141 ; 200 ; 183$ & 1.79 & - & - \\
\hline germacrene B & 1563 & $121 ; 93 ; 41 ; 107 ; 204$ & - & 1.51 & - \\
\hline spathulenol & 1573 & $43 ; 41 ; 205 ; 119 ; 220$ & 7.93 & 3.38 & 3.52 \\
\hline caryophyllene oxide & 1583 & $91 ; 67 ; 41 ; 109 ; 121 ; 138$ & 1.88 & 1.54 & 0.66 \\
\hline$\delta$ - cadinol & 1638 & $161 ; 43 ; 119 ; 105 ; 41 ; 204 ; 222$ & - & 0.7 & 1.72 \\
\hline cedren-13-ol & 1644 & $119 ; 41 ; 91 ; 105 ; 220$ & 1.02 & 0.65 & 1.58 \\
\hline$\alpha$-cadinol & 1656 & $43 ; 95 ; 121 ; 41 ; 204 ; 222$ & - & 1.04 & 2.61 \\
\hline acorenone & 1685 & $220 ; 41 ; 159 ; 91 ; 191 ; 105$ & 2 & 1.56 & - \\
\hline (E)-phytol & 1945 & $71 ; 57 ; 43 ; 123 ; 295$ & 2.33 & - & 0.81 \\
\hline solidagenone & 2385 & $82 ; 81 ; 41 ; 111 ; 95 ; 316$ & 0.9 & 0.67 & 1.85 \\
\hline
\end{tabular}

${ }^{1}$ EOCS $=$ central stem; EODI $=$ inflorescences; EOFI $=$ fresh inflorescences.

${ }^{2}$ Compounds are listed in order of their elution from a DB- 5 column.

${ }^{3} \mathrm{RI}=$ retention indices relative to $\mathrm{C} 8-\mathrm{C} 28 n$-alkanes. 
by the fact that the sesquiterpene be precursor for the biosynthesis of several other sesquiterpenes (Tab. 2) (Him et al. 2008). Some of the identified compounds of the essential oil samples have been reported for their antinociceptive activity such as $\delta$-cadinene, $\alpha$-pinene, myrcene, germacrene $\mathrm{D}$, limonene and caryophyllene oxide (Collier et al. 1968; Him et al. 2008). The comparison of the major compounds in the analyzed samples from $S$. chilensis is showed in Table 3.

Table 3 - Comparison of major volatile compounds in the analyzed samples from S. chilensis aerial parts detected/ extracted by SPME and hydrodistillation.

\begin{tabular}{|c|c|c|}
\hline Aerial part & Major compounds & Method of detection/extraction \\
\hline \multirow[t]{2}{*}{ Central stems } & $\begin{array}{l}\text { Germacrene D, bornyl acetate, } \gamma \text {-elemene, } \beta \text {-caryophyllene, } \\
\text { limonene }\end{array}$ & SPME \\
\hline & $\begin{array}{l}\text { Germacrene } \mathrm{D}, \gamma \text {-elemene, bornyl acetate, spathulenol, } \\
\beta \text {-caryophyllene }\end{array}$ & hydrodistillation \\
\hline \multirow[t]{2}{*}{ Dry inflorescences } & $\begin{array}{l}\text { Germacrene } \mathrm{D},(\mathrm{Z}) \text { - } \beta \text {-farnesene, } \beta \text {-caryophyllene, bornyl } \\
\text { acetate }\end{array}$ & SPME \\
\hline & Germacrene $\mathrm{D}, \beta$-caryophyllene, $\gamma$-elemene, bornyl acetate & hydrodistillation \\
\hline \multirow[t]{2}{*}{ Fresh inflorescences } & Limonene, germacreno D, bornyl acetate & SPME \\
\hline & Germacrene $D$, limonene, $\gamma$-elemene, $\beta$-caryophyllene & hydrodistillation \\
\hline
\end{tabular}

The antinociceptive effect was observed in the three oils samples, the EOCS have inhibited about $35 \%$ of number of writhings $(29.42+4.6)$, the EOFI have inhibited about $53 \%$ of number of writhings $(21.25 \pm 4.2)$, EODI have inhibited about $49 \%$ of number of writhings $(23.08 \pm 1.4)$ and the standard substance diclofenac have inhibited about $67 \%$ of number of writhings $(14.83 \pm 3.1)$. A difference in the antinociceptive activity of about $6 \%$ between dry and fresh inflorescences was observed (Tab. 4). Chemically, there was the loss of the most volatile substances in the dry sample due to their evaporation of the some monoterpenes as camphene, $\beta$-mircene, $\alpha$-phellandrene that are present only in the EOFI and limonene, (Z)- $\beta$-ocimene, $\beta$-cubebene, cedren-13-ol and $\alpha$-cadinol which are present in only one half of the EODI sample concentration.

\section{Conclusions}

Germacrene D is also previously reported as the main compound of many species of the Solidago genus. The limonene, that is widely used as pharmaceutical ingredient in industry to produce bath products as soap and room sprays due to their pleasant smell, comprises about $10 \%$ of the essential oil of fresh inflorescences. The antinociceptive activity of many terpenes present in essential oils, combined with the chemical complexity of these

Table 4 - Antinociceptive effect of EOCS ${ }^{1}$, EODI ${ }^{1}$ and EOFI ${ }^{1}$.

\begin{tabular}{lccc}
\hline Treatment & Dose $\mathbf{( m g / K g})$ & Number of writhings $^{\mathbf{2}}$ & \% Inhibition $^{\text {I }}$ \\
\hline Saline & - & $45.14 \pm 3.3$ & $0 \%$ \\
EOCS & 1 & $29.42 \pm 4.6$ & $34.84^{* *}$ \\
EOI & 1 & $23.08 \pm 1.4$ & $48.86^{* *}$ \\
EOFI & 1 & $21.25 \pm 4.2$ & $52.93^{* * *}$ \\
Diclofenac & 50 & $14.83 \pm 3.1$ & 67.14 \\
\hline
\end{tabular}

${ }^{1}$ EOCS $=$ central stem $S$. chilensis essential oil; EODI = inflorescences of $S$. chilensis essential oil; EOFI = fresh inflorescences of $S$. chilensis essential oil; $\mathrm{n}=12$.

${ }^{2}$ Values represent mean \pm S.E.M.; ${ }^{* *} \mathrm{P}<0.01 ; * * * \mathrm{P}<0.001$. 
oils, shows the synergistic potential that the Solidago chilensis essential oil could exerts, acting through different mechanisms of action, in addition to their potential in developing new topical analgesics, even as adjuvants in pharmaceutical formulations. This is the fisrt report about the SPME analysis and about the pharmacological activity of the Solidago chilensis Meyen essential oil.

\section{Acknowledgments}

The authors are grateful to Pharmaceutical Technology Institute (Farmanguinhos), Military Institute of Engineering (IME) and Oswaldo Cruz Institute (IOC), for infrastructural support; Agroecological Phytomedicine Platform (PAF/ Fiocruz), for the identification, cultivation and supply of Solidago chilensis; Foundation for Scientific and Technological Development in Health (FIOTEC), Coordination for the Improvement of Higher Education Personnel (CAPES) and National Council for Scientific and Technological Development (CNPq), for financial support and scholarships.

\section{Conflicts of interest}

The authors declare no conflict of interest.

\section{References}

Abad MJ, Bedoya LM \& Bermejo P (2013) Fighting multidrug resistance with herbal extracts, essential oils and their components. Elsevier, London. Pp. 205-222.

Azar PA, Porgham-Daryaasari A, Saber-Tehrani M \& Soleimani M (2012) Analysis of the volatile compounds in Nepeta crispa Willd using improved HS-SPME-GC-MS and comparison with conventional methods. Acta Chromatographica 24: 75-84.

Bülow N \& König WA (2000) The role of germacrene $\mathrm{D}$ as a precursor in sesquiterpene biosynthesis: investigations of acid catalyzed, photochemically and thermally induced rearrangements. Phytochemistry 55: 141-168.

Collier HDJ, Dinnin LC, Johnson CA \& Schneider C (1968) The abdominal response and its suppression by analgesic drug in the mouse. British Journal of Pharmacology and Chemotherapy 32: 295-310.

Digest R (2001) Segredos e virtudes das plantas medicinais. Reader's Digest Brasil, Rio de Janeiro. $416 \mathrm{p}$.

Duarte MCT, Figueira GM, Sartoratto A, Rehder VLG \& Delarmelina C (2005) Anti-Candida activity of Brazilian medicinal plants. Journal of Ethnopharmacology 97: 305-311.

Fujita E, Fuji K, Nagao Y \& Node M (1979) Bulletin of the Institute for Chemical Research. Vol. 56. Kyoto University, Kyoto. Pp. 356-380.

Fujita S (1991) On the components of the essential oils of Solidago virgaurea Linn. ssp. (Miscellaneous contributions to the essential oils of plants from various territories. Part 52). Nippon Nogei Kagaku Kaishi 64: 1729-1733; through Chemical Abstracts 114: 98252.

Gressler V, Dias GOC, Simionatto E, Dessoy ECSM \& Morel AF (2003) Isolamento de sesquiterpeno a partir do óleo volátil de Solidago microglossa D.C. In: $11^{\circ}$ Encontro de Química da Região Sul. Resumos dos trabalhos apresentados no $11^{\circ}$ Encontro de Química da Região Sul. SBQSUL, Pelotas. 100p.

Him A, Ozbek H, Turel I \& Oner AC (2008) Antinoceceptive activity of alpha-pinen and fenchone. Pharmacologyonline 3: 363-369.

Kalemba D (1992) Phenolic acids in four Solidago species. Pharmazie 47: 471-472.

Kalemba D (1998) Constituents of the essentials oil of Solidago virgaurea L. Wiley. Flavour and Fragance Journal 13: 373-376.

Kasali AA, Ekundayo O, Paul C \& Konig WA (2002) Epi-Cubebanes from Solidago canadensis. Phytochemistry 59: 805-810.

Li Q, Pan SH, Zhu XW, Tan L \& Cao YF (2011) Anticancer activity and chemical composition of leaf essential oil from Solidago canadensis $L$. in China. Advanced Materials Research 1584: 347-353.

Mercandeli A, Bessa G, Ronchi S, Segato T \& Silva A (2012) Evidence for the safe use of the extract from the Brazilian arnica, Solidago chilensis Meyen, in primary health care. Chinese Medicine 3: 4-8.

Miguel S (2007) A Arnica desvendada. Jornal da USP 2: $22-26$.

Oliveira F, Akisue G \& Akisue MK (1998) Farmacognosia. Atheneu, Rio de Janeiro. Pp. 379-383.

Paula-Freire LIG, Okamoto PB, Molska GR, Alves de Oliveira T, Gracia VP, Correa L, MalpezziMarinho ELA \& Marinho EAV (2006) Verificação da toxicidade aguda do extrato hidroalcoólico de arnica do campo (Solidago chilensis Meyen) via oral em camundongos. $38^{\circ}$ Congresso Brasileiro de Farmacologia e Terapêutica Experimental. Livro de Resumos. Setor 10, Toxicologia. Available at $<$ https:// sbfte.org.br/Setor10.pdf>.

Sangwan NS, Farooqi AHA, Shabih F \& Sangwan RS (2001) Regulation of essential oil production in plants. Plant Growth Regulation 34: 3-21.

Schnaubelt K (2005) Essential oil therapy according to traditional Chinese medical concepts. The International Journal of Aromatherapy 15: 98-105.

Shah SMM, Ullah F, Shah SMH, Zahoor M \& Sadiq A (2012) Analysis of chemical constituents and antinociceptive potential of essential oil of Teucrium Stocksianum bioss collected from the North West of Pakistan. BMC Complementary and Alternative Medicine 12: 244. 
Silva AG, Sousa CP, Koehler J, Fontana J, Christo AG \& Guedes-Bruni RR (2010) Evaluation of an extract of Brazilian arnica (Solidago chilensis Meyen, Asteraceae) in treating lumbago. Phytotherapy Research 24: 283-287.

Sousa DP (2011) Analgesic-like activity of essential oils constituents. Molecules 16: 2233-2252.

Steliopoulos P, Sta WM, Adamb K \& Mosandla A (2002) Biosynthesis of the sesquiterpene germacrene D in Solidago canadensis: ${ }^{13} \mathrm{C}$ and ${ }^{2} \mathrm{H}$ labeling studies. Phytochemistry 60: 13-20.

Sung MH, Lee IO, Son IK, Park NS, Kim MR \& Moon JGKDC (1999) Cytotoxic constituents from Solidago virga-aurea var.gigantea. Archives of Pharmacal Research 22: 633-637.

Torres LMB (1985) Estudo químico da espécie Solidago microglossa DC. Tese de Doutorado. USP, São Paulo. 175p.

Valverde SS, Oliveira TB \& Souza SP (2013) Solidago chilensis Meyen (Asteraceae). Revista Fitos 7: 131-136.

Vieira RF (1999) Conservation of medicinal and aromatic plants in Brazil. In: Janick J Alexandria (ed.) Perspectives on new crops and new uses. ASHS Press, Alexandria. Pp. 152-159.

Vila R, Mundina M, Tomi F, Furlán R, Zacchino S, Casanova J \& Cañigueral S (2002) Composition and antifungal activity of the essential oil of Solidago chilensis. Planta Medica 68: 164-167.

Weyerstahl P, Marschall H, Christiansen C, Kalemba D \& Góra J (1993) Constituents of the essential oil of Solidago canadensis ("Goldenrod") from Poland-A correction. Planta Medica 59, Vol. 3: 281-282.

Yoshihara K, Yoshimoto O, Sakai T \& Hirose Y (1969) Germacrene D, a key intermediate of cadinene group compounds and bourbonenes. Tetrahedron Letters 27: 2263-2264.

Sample Availability: samples of the essential oils of Solidago chilensis Meyen are available from the authors. 